\title{
The Effect Of Puppets as Teaching Media on the Speaking Competency
}

\author{
I Made Lanang Wedana', Wayan Suarnajaya ${ }^{2}$, Luh Diah Surya Adnyani ${ }^{3}$ \\ ${ }^{123}$ English Language Education, Universitas Pendidikan Ganesha, Indonesia
}

Keywords:

Speaking Competency,

Puppets,

Conventional

Correspondance address:

E-mail: lanangwedana96@mail.com (I Made Lanang Wedana)

\begin{abstract}
This study focused on investigating the effect of puppets as a teaching media on students' speaking competency. It was an experimental research administering post-test only control group design. The population was the eighth-grade students of SMP N 6 Singaraja. The samples were VIII B1 class as experimental group and VIII B3 as a control group. The experimental group was treated by using puppets as teaching media, whereas the control group was treated by using the conventional technique. The instruments used in this study to collect the data were the teaching scenario and post-test in the form of a speaking test. The data were then analyzed descriptively, inferentially and effect size. The result was significant. It can be seen from both group's mean score where the experimental group's score was 93.84 while control group's score was 90.22 the value of tob ( $t$ observed) was 2.111 and it was higher than tcv ( $t$ critical value) that was 1.669 ( $a=0.5)$. It indicates that there is a significant effect on students' speaking competency who were taught by puppet and those who were taught by conventional technique.
\end{abstract}

\section{Introduction}

The development of MEA (Masyarakat Ekonomi ASIA) makes Indonesian people need to learn English, which has an important role as a language used among ASEAN member countries and also international language because it is the language of science, politics, economics, education, information, and technology. Accordingly, it is necessary to learn English as it is essential for communication and development (Hamdona, 2007). As a result, teaching English has been started since the people are in their early age.

In schools, there are four skills that are expected to be mastered by the students, namely: listening, speaking, reading, and writing. From those four skills, speaking plays an important role in language learning. Therefore, speaking skill is important for students to master. The objective that needs to be achieved by the students is the ability to express and to respond to a simple instruction and information in the context of a class with the use of language functions such as giving instructions, asking and giving things, asking and giving services, and introducing themselves. It is expected that the students can use the language functions in real communication in their daily lives.

However, speaking is still assumed to be a difficult part of learning English, especially for students in junior high school in Indonesia. Students are still lack of ability in speaking English, even though English has become a compulsory subject in junior high school and senior high schools. Students who are able to speak a simple language are still very limited. Pranawati and Kumalarini (2013) add that Indonesian students in junior high school are not good at speaking English because there are some teachers who still use traditional and monotonous ways of teaching. Therefore, 
Indonesian students become passive and tend to be unconfident when they are asked by their teacher to speak in front of the class. In line with that statement Siregar, Ernati, and Tavriyanti (2014) mention two reasons that make students hard in learning speaking namely, first, it comes from the students themselves who are shy and never try to practice their speaking. Second, it is because their teachers do not apply interesting techniques and media in the teaching and learning process. Moreover, based on the pre-observation and informal interview that was found by the researcher in which there are no media used in teaching speaking competency. It made the students feel bored and did not give a positive response to the learning process.

There are several things that can make teaching and learning processes run effectively, such as media, teaching techniques, teaching strategy, and, teaching approach. As one important aspect of the process of learning English, media need to be prepared carefully in order to have an effect on the learning process. The media can also make the students develop their characters by involving them in the speaking competency process. One media that can be used by the teacher in teaching speaking is Puppets.

Nurhayati (2011) and Dewantara (2018) states that a creative teacher usually uses tool or media to help him or her in delivering messages while teaching. The teacher believes that it will be better to use appropriate media to attract the students' attention and to make them understand the material easier. She also states that puppet is a small figure of the object such as animals, people, or fantasy things that are interesting, colorful and can be operated by anyone. Children usually love to play it. They usually use their imagination to play it. Puppets can be used for practicing grammar rules in a more light-hearted way, reviewing the materials with humor and explaining the materials in a fun way. There are many kinds of puppets that can be used in the classroom such as hand puppets, finger puppets, rod puppets, marionette, and shadow puppets. Those kinds of puppets are very easy to get or make. People can buy them in a store or make them themselves. By using both tools, the students are expected to be more interested in having a speaking class. They are also expected to have more opportunities to practice speaking, which in turn will make them attend in the speaking class.

A study on the use of puppet has been conducted by Prasetyaningrum (2017). This research was done in the Language and Art Department, Hamzanwadi University Selong, Indonesia. The result of the research showed that puppet usage was significantly effective in teaching speaking for junior high school students. Another research has been done by Yulianti and Latief (2014). In their research, they tried to help teachers enhance their insight that the use of media is not only for teaching and learning in the classroom but also it can be effectively used to build students' motivation and performance in joining English competition activities. In this case, the study focuses on the storytelling competition for the students to show their speaking ability and their ability in using the puppet media and pop up the picture.

In this present study, puppets were applied for different grades of students in another setting, in order to know whether the media were effective in different situations. This study is an experimental study in which the purpose of this study is investigating whether puppet as media has a significant effect or not on students' speaking competency between students taught by using puppets as media and students taught by conventional technique. This study was conducted in the eighth grade students of SMP Negeri 6 Singaraja in the academic year 2018/2019 


\section{Methods}

This research is an experimental research which is design by using Posttest-Only Control Group Design. This is used based on the objective of the study is to find out the significant difference of English speaking competency between the experimental and control groups. It is done because of the time limitation. The population of this research is the eighth grade students at SMP N 6 Singaraja in academic year 2018/2019.

To make sure all population has the same chance to be chosen as the sample of this study, the lottery was applied. Moreover, two homogeneous classes are needed as a sample. The two samples are chosen randomly through a lottery. Through lottery two classes selected the sample was VIII B1 as the experimental group and VIII B3 as the control group.

There are several instruments that will be used in this study, namely: Speaking test, scoring rubric for speaking test and Teaching scenario. The results of the values obtained from both groups, both experimental and control groups will be analyzed descriptively and inferential statistics. Descriptive analysis consists of mean, media, mode, range, standard definition, and variance. Whereas in inferential statistical analysis, the data obtained were analyzed using $t$ test. In this study SPSS 24 will be used.

\section{Results and Discussion}

The findings in this study concerned the result of the post-test score. The result of the posttest score was analyzed using descriptive analysis and inferential analysis. The descriptive analysis calculated the mean, median, mode, range, standard deviation, and variance of both groups' posttest result. Inferential analysis calculated through t-test. The results of the analysis show whether the difference between the mean score of the two samples was significant or not.

First, the data were analyzed descriptively in search of the mean, median, mode, range, standard deviation and variance. The result of descriptive statistical analysis can be seen below.

Table 1. Summary of the Descriptive Analysis Result

\begin{tabular}{llcccccc}
\hline Score & Group & Mean & Median & Mode & Range & Std. Dev. & Variance \\
\hline $\begin{array}{l}\text { Experimental } \\
\text { Group }\end{array}$ & 93.84 & 94.50 & 100 & 19 & 5.74 & 33.03 \\
& & & & & & \\
\hline Control Group & 90.22 & 89.50 & 100 & 28 & 7.83 & 61.33 \\
\hline
\end{tabular}

The result shows that there were some differences in several categories of descriptive statistical analysis. The mean score of experimental was 93.84 which was higher than the control group which was only 90.22 . Then, the median of the experimental group was 94.50 while in the control group the median was 89.50 . The most frequently appeared score was a bit the same. In the experimental and control group, the mode was 100. Next, the range of score in both groups was different. The range in experimental was 19 in which the highest score was 100 and the lowest score was 81 . In the control group, the highest score was 100 and the lowest one was 72 . Hence, the range was 28. Furthermore, the variance of the experimental group was 33.03 and the standard deviation was 5.74. While the control group, the variance was 61.33 and the standard deviation was 7.83.

Based on the explanation above, it can be temporarily concluded that experimental group which was the group taught using puppets as teaching media achieved a higher score than the 
control group which was taught using the conventional technique (three-phase technique). The inferential analysis provided information about the significant effect between Teaching using Puppet as media and Conventional technique (three-phase technique) on students' speaking competency. Ttest was used to analyze the data. However, there were two requirements that need to be fulfilled before conducting the t-test. They were the normality of data distribution and the homogeneity of data variance. The first requirement was the data of two sample groups should be in the normal distribution. In order to do that, the Kolmogorov-Smirnov statistic test was used. In this statistic test, the data were categorized as normally distributed if the significance value (Sig.) exceeds the value 0.05 . If the significance value (Sig.) is low or less than 0.05 , the distribution of the data was not in a normal distribution.

The second requirement which is the data variance should be homogeneous was analyzed by using a Levene statistic test. In this statistic test, the data variance of the two sample groups was considered as homogeneous if the significance value (Sig.) is higher than the value of 0.05 . If the significance value (Sig.) was less than 0.05 , the data variance of the two sample groups were not considered as homogeneous. The data were analyzed using t-test after having normality and homogeneity to find out whether there is a significant effect of teaching using puppets on the students' speaking competency or not. Based on the result of t-test there was a significant effect on speaking competency of the eighth grade students who are taught by using puppets as teaching media and those who are taught by conventional technique at SMP Negeri 6 Singaraja in Academic Year 2018/2019.

The focus of this study is to investigate the significant difference of teaching using the puppets as media on students' speaking competency in the eighth grade students of SMP Negeri 6 Singaraja in academic year 2018/2019. There were two groups selected as the sample of the study. Those classes, later on, were assigned as an experimental class and control class. The experimental group applied to teach using the puppets as media, while the control group applied a conventional technique (three-phase technique). The two groups were given the same post-test after finishing the treatments. The data of the post-test were analyzed by using descriptive and inferential statistical analysis.

First, descriptive statistical analysis revealed that the experimental group achieved a higher score than the control one. The mean score for the experimental group was 93.84 while another group which was the control group achieved 90.22 . In a sight, there was only 3.62 range of score between both mean scores, but it still could be inferred that students in the experimental group achieved a higher score. From this calculation, it could be temporarily concluded that the experimental group which was taught by using puppets as a teaching media achieved a better score than the one which was taught by using conventional teaching technique or without puppets as teaching media.

Secondly, from the inferential statistics, $t$-test revealed that there was a significant difference from the use of puppets as a teaching media towards the students' speaking competency between the experimental and control group. This was due to the result of tobs which was 2.111 and higher than $\mathrm{tcv}$ which is 1.669 ( $\mathrm{df}=62, \alpha=0.05$ ). This accepted the alternative hypothesis $(\mathrm{Ha})$ in which states that there is a significant difference on students' speaking competency between students taught using puppets as a teaching media and students taught using conventional technique or without using puppet in eighth grade students of SMP Negeri 6 Singaraja in academic year 2018/2019 and rejected the null hypothesis (HO).

In implementing puppets and conventional technique the teacher was guided by teaching scenario when teaching both groups. There were four meetings, both in the experimental group and control group. The topic that was taught in experimental and control class was a recount text. During the treatment, the experimental class was treated by using the puppets. There is a theory that adapted from Pujianto (2011) to teach the students by using the puppet as a media in teaching. In experimental class, the teacher used puppet while discussed the topic during the teaching and learning process. Meanwhile, in the control group, the students who were taught by using 
conventional technique were treated similarly but both experimental and control group different is in the term of media only. In the experimental group, the teacher used the puppets while explained the topic. Puppet is a small figure of the object such as animals, person, or fantasy things that is interesting, colorful and can be operated by someone. Children usually love to play puppets.

They usually use their imagination to play it. The students were excited about the puppets. The atmosphere was different since the teacher started to use the puppets because using puppets as a teaching media is a good way to get the students' attention and keep them engaged during the learning process. The students seemed to enjoy the activity. Besides, they were not afraid to express their works in front of the class and enjoyed their performances, it supported Giles and Tunks (2008) who said through puppets, children feel empowered to speak. Children can pick up a puppet, begin speaking in a different voice, and quickly take the personality of the character they are portraying. This could be seen from their full attention from beginning until the performance. It supported Giles and Tunks (2008) who stated puppets are a valuable means and they can assist students to promote oral language skills and confidence in speaking. Besides, it also supported Nurhayati (2011) who stated the teacher believes that it will be better to use appropriate media to attract the students' attention and to make them understand the material easier.

The use of puppets in the experimental class also gave benefit to the teacher that wants to create a good atmosphere in the class. It supported Insani (2013) who mention that the use of puppets was an appropriate and effective approach in teaching and learning activities. It helped the teacher to teach in ease situation, particularly in engaging the students, creating a good atmosphere and organizing the class.

In the control group, the teacher used the conventional technique (three-phase technique). In this technique, the activities are divided into three phases, namely pre-activity, whilst-activity, and post-activity. In the first phase, the teacher generates the students' interest about topic by conducting some activities, such as setting the context, linking students' prior knowledge, predicting the content of the material and etc. the next phase, the teacher can use a sort of task based activities, the learners are required to finish some tasks with the information they have extracted from the text. And in the last phase, the teacher determines how well the students have understood what they read about. It can be done by conducting some activities such as problem solving, summarizing, group discussion and writing as follow up. In this situation, the students looked passive during the learning process. Besides, the students were afraid to express their works in front of the class. .It supports Khalid and Azeem (2010) who stated that conventional technique is common in education and it cannot create active as well as creative students in the classroom learning process.

Comparing this research to the previous research, most of the studies showed the same result that the use of puppets as teaching media was better than the conventional technique (threephase technique). In this research, the researcher found that puppets and three-phase technique can give a good result but in this case, the puppets can give better result than three-phase technique. It also concluded that when the puppets are used in teaching, it enhances learner's positive attitude towards the course. It also influences students' performances positively. In conclusion, the result of this study proved that the use of puppets as a teaching media was successful in giving a significant effect on the score of students' speaking competency reading in the eighth grade students of SMP Negeri 6 Singaraja in academic year 2018/2019. This is proved by the result of descriptive statistical analysis and strengthened by inferential statistical analysis in which the average score of the experimental group was higher than the control one. Furthermore, inferentially, t-test showed that tobs was higher than tcv which then added a significant difference in the result of both groups. And those all proved that experimental achieved a higher score than control under the influence of puppets as a teaching media implementation along with the research. This also directly accepted the alternative hypothesis $\mathrm{(Ha}$ ) that "there is a significant difference on students' speaking competency between students taught using puppets as a teaching media and students taught using the 
conventional technique or without using puppet in eighth grade students of SMP Negeri 6 Singaraja in academic year 2018/2019".

\section{Conclusion}

This study concludes that there was a significant effect of teaching using puppets as a media on the speaking competency of the eighth grade students of SMP Negeri 6 Singaraja in the academic year 2018/2019. Students who were taught by using puppets got better speaking score than the students who were taught by using a conventional technique (three-phase technique). This was supported by the results of two statistical analysis namely descriptive and inferential statistical analysis.

The mean score of both the experimental and in control group show that experimental achieved higher and better than the control group. Mean score of the experimental group was 93.84 while control group achieved 90.21. Although the range was not too far between these scores still experimental achieved a better score. Then this was strengthened by inferential statistical analysis in which the result of $t$-test revealed $t_{0}$ was 2.111 which was higher than $t_{\mathrm{cv}}$ which is 1.669 (df $=62, \alpha=$ 0.05). Furthermore, the conclusion derives to an acceptance of alternative hypothesis which states that 'there was a significant effect between students' speaking competency who taught by using puppet and those taught by conventional technique. In addition, the researcher also using effect size calculation to measure the treatment effect. The result of the effect size in this study was 0.53 , it can be categorized as a medium score. It means that teaching using the puppets as a media gave medium influence on students' speaking competency and had a positive effect on students' speaking competency.

\section{References}

Dewantara, IPM. 2018. Text Attributed with Language Attitude in Indonesian Language Instruction as The Efforts to Knit Nationalism in a Frame of Diversity. Global Conference on Teaching, Assessment, and Learning in Education (GC-TALE 2017) Vol 42, 2018. https://doi.org/10.1051/shsconf/20184200026

Giles, R. C., Tunks, K. W. .2008. Puppet Play: Dramatic Benefits for Young Performers. Retrieved September 9, 2016 from http:// www. earlychildhoodnews.com /earlychildhood/article_view.aspx?ArticleID=745

Nurhayati, D. .2011. The Effectiveness of Using Hand Puppet to Improve Students' Speaking Skills in Performing Adjacency Pairs. English Department of Language And Art Semarang.

Prasetyaningrum., A. .2017. The Use of Puppet in Teaching Speaking for Junior High School Students.

Yulianti, R., \& Latief, M. A. .2014. Puppet and pop up the picture as the storytelling media to build students' motivation in the English competition. 